ISSN : 2615-1995, E-ISSN : 2615-0654

J. Madani., Vol. 4, No. 1, Maret 2021 (1 - 11)

(C)2018 Lembaga Kajian Demokrasi

\title{
Pengaruh Motivasi Dan Intensi Pengguna Media Sosial Terhadap Kepedulian Sosial Pada Mahasiswa Universitas Pamulang
}

\author{
Ibrahim Bali Pamungkas \\ Fakultas Ekonomi, Universitas Pamulang \\ dosen01015@unpam.ac.id \\ Yuliati Ningsih \\ Program Pasca Sarjana Magister Manajemen, Universitas Pamulang \\ yuliatiningsih1992@gmail.com \\ Angga Pratama \\ Fakultas Ekonomi, Universitas Pamulang \\ dosen02155@unpam.ac.id
}

\begin{abstract}
Abstrak
Penelitian ini bertujuan untuk Untuk mengetahui pengaruh secara bersama-sama motivasi dan intensi pengguna media sosial secara bersama-sama terhadap kepedulian sosial. Subjek penelitian ini adalah mahasiswa tingkat 2 program studi manajemen Universitas Pamulang. Penelitian ini merupakan penelitian kuantitatif jenis deskriptif. Metode pengumpulan data dengan menggunakan observasi dan kuesioner. Teknik pengambilan sampel dengan menggunakan simple random sampling. Keabsahan data dalam penelitian ini menggunakan Uji Validitas, Uji Reliabilitas, dan Uji Asumsi Klasik. Hasil penelitian menunjukkan bahwa terdapat pengaruh positif dan signifikan secara secara simultan antara Motivasi (XI) dan Intensi Pengguna Media Sosial (X2) terhadap Kepedulian Sosial (Y) pada Mahasiswa Universitas Pamulang Tingkat 2 Fakultas Ekonomi Jurusan Manajemen Kelas Eksekutif. Hal ini dibuktikan dengan berdasarkan tabel Output di atas dapat dijelaskan bahwa, persamaan regresi linear berganda $Y=a+$ b1x1 + b2x2 adalah $Y=18,578+0,251(x 1)+0,346(x 2)$.
\end{abstract}

Kata Kunci : Motivasi, Intensi Pengguna Media Sosial, Kepedulian Sosial

\begin{abstract}
This study aims to determine the joint influence of motivation and intentions of social media users on social care. The subjects of this study were students of level 2 of the Pamulang University management study program. This research is a descriptive quantitative research. Methods of data collection using observations and questionnaires. The sampling technique used simple random sampling. The validity of the data in this study used the validity test, reliability test, and classical assumption test. The results showed that there was a positive and significant effect simultaneously between Motivation (XI) and Intention of Social Media Users (X2) on Social Concern (Y) in Pamulang University Level 2 Students of the Faculty of Economics,
\end{abstract}


Management Executive Class. This is evidenced by based on the Output table above it can be explained that, the multiple linear regression equation $Y=a+b 1 \times 1+b 2 \times 2$ is $Y=18.578+0.251(x 1)+0.346(x 2)$.

Keywords : Motivation, Intention of Social Media Users, Social Care

\section{PENDAHULUAN}

Manusia dalam memenuhi kebutuhan hidup diri pribadi tidak dapat melakukan sendiri melainkan memerlukan bantuan dari orang lain. Terdapat ikatan saling ketergantungan diantara satu orang dengan yang lainnya. Artinya kelangsungan hidup manusia berlangsung dalam suasana saling mendukung dalam kebersamaan. Manusia dituntut mampu bekerjasama, saling menghormati, serta toleran dalam hidup bermasyarakat. Manusia sebagai makhluk individu dan sosial akan menampilkan tingkah laku tertentu, akan terjadi peristiwa saling mempengaruhi antara individu yang satu dengan individu yang lain.

Hasil dari peristiwa saling mempengaruhi menimbulkan perilaku sosial yang mewarnai pola interaksi tingkah laku setiap individu. Perilaku sosial individu merupakan sifat relatif untuk menanggapi orang lain dengan cara-cara yang berbeda-beda. Misalnya dalam melakukan kerjasama, ada orang yang melakukannya dengan bersemangat, sabar dan selalu mementingkan kepentingan bersama diatas kepentingan pribadinya. Sementara di pihak lain, ada individu yang bermalas-malasan, tidak sabaran dan hanya ingin mencari untung sendiri. Individu yang perilakunya mencerminkan keberhasilan dalam proses sosialisasi dikatakan sebagai individu yang sosial.

Individu yang perilakunya tidak mencerminkan proses sosialisasi disebut non sosial. Perilaku non sosial adalah perilaku a-sosial dan anti sosial. Individu yang berperilaku a-sosial tidak mengetahui apa yang yang dituntut oleh kelompok sosial, sehingga berperilaku yang tidak memenuhi tuntutan sosial contohnya mengisolasi diri atau menghabiskan waktunya untuk menyendiri. Individu yang berperilaku anti sosial mengetahui hal-hal yang dituntut kelompok tetapi karena sikap permusuhannya menjadi melawan norma kelompok.

Pendidikan merupakan suatu proses perkembangan kecakapan seseorang dalam bentuk sikap dan perilaku yang berlaku dalam masyarakat. Proses di mana seseorang dipengaruhi oleh lingkungan yang terpimpin khususnya di dalam lingkungan sekolah sehingga dapat mencapai kecakapan sosial dan dapat mengembangkan kepribadiannya. Dengan kata lain, pendidikan juga dapat diartikan sebagai wahana pengubahan kepribadian dan pengembangan diri.

Oleh karenaitu pendidikanjuga akan membawa dampak yang besar terhadap peningkatan kualitas dan perilaku hidup seseorang. Hal ini sesuai dengan penjabaran fungsi pendidikan nasional dalam UU Nomor 20 Tahun 2003 tentang Sistem Pendidikan Nasional pada pasal 3, yang berbunyi: "Pendidikan nasional berfungsi mengembangkan kemampuan dan membentuk watak serta peradaban bangsa yang bermartabat dalam rangka mencerdaskan kehidupan bangsa, bertujuan untuk berkembangnya potensi peserta didik agar menjadi manusia yang beriman dan bertakwa kepada Tuhan Yang Maha Esa, berakhlak mulia, sehat, berilmu, cakap, kreatif, mandiri, dan menjadi warga negara yang demokratis serta bertanggung jawab."

Perguruan Tinggi merupakan lembaga pendidikan formal, dimana terjadi interaksi dari berbagai pihak yang bertujuan untuk menciptakan manusia sebagai manusia yang berkualitas dan bermoral, untuk menjadi manusia yang berkualitas dan bermoral mahasiswa harus mampu menunjukkan perilaku yang baik (positif) khususnya perilaku belajar ketika mahasiswa di kelas. Keberagaman karakteristik mahasiswa dalam satu kelas menyebabkan banyaknya perbedaan pada perilaku belajar mahasiswa di kelas. Iklim belajar mengajar di kelas ditentukan oleh bagaimana perilaku belajar mahasiswa ketika di kelas. Menurut Hana Nur Rahmawati et al (2017) dengan penggunaan menggunakan media sosial dengan durasi rendah akan memiliki motivasi belajar tinggi.

Peduli sosial merupakan salah satu pendidikan karakter yang harus diterapkan pada proses pembelajaran. Menurut Muchlas Samani dan Hariyanto (2011) peduli sosial yaitu memperlakukan orang lain dengan sopan, bertindak santun, toleran terhadap perbedaan, tidak menyakiti orang lain, mau mendengar orang 
lain, mau berbagi, tidak merendahkan orang lain, tidak mengambil keuntungan dari orang lain, mampu bekerja sama, mau terlibat dalam kegiatan masyarakat, menyayangi manusia dan makhluk lain, setia, cinta damai dalam menghadapi persoalan.

Menurut Cruz (2017) mengungapkan bahwa aspek demografi khususnya latar belakang pendidikan konsumen menjadi salah satu faktor yang paling berpengaruh terhadap pola konsumsi konsumen ramah lingkungan. Lalu menurut Budi Susilo (2018) segmen pengguna media sosial mempunyai tingkat keaktifan normal dan pasif dalam merespon konten iklan.

Sedangkan motivasi belajar adalah dorongan atau penggerak yang menyebabkan seseorang untuk belajar atau mempelajari materi pelajaran. Semakin tinggi motivasi belajar seseorang, maka semakin tinggi pula hasil belajarnya.

Menurut Hamzah B.Uno (2011), motivasi adalah dorongan yang ada dalam diri individu yang dapat menggerakkan seseorang itu untuk melakukan sesuatu. Dalam proses pembelajaran, motivasi belajar merupakan aspek yang sangat penting. Dalam belajar sangat diperlukan motivasi. Motivation is an essential condition of learning. Hasil belajar akan menjadi optimal, jika ada motivasi. Semakin tepat motivasi yang diberikan, akan semakin berhasil juga pelajaran itu. Pada mulanya siswa tidak ada hasrat untuk belajar, tetapi karena ada sesuatu yang dicari, muncullah minat untuk belajar.

Hal ini sejalan dengan rasa keingintahuan dia yang akhirnya mendorong siswa untuk belajar. Sikap inilah yang akhirnya mendasari dan mendorong ke arah sejumlah perbuatan dalam belajar. Jadi, motivasi yang berfungsi sebagai pendorong ini mempengaruhi sikap apa yang seharusnya siswa ambil dalam rangka belajar. Menurut Lalu Hasgar et al (2020) bahwa terdapat pengaruh pembelajaran kooperatif tipe STAD terhadap hasil dan motivasi belajar siswa. Selanjutnya menurut Shinta (2019) adanya hubungan antara kebiasaan beljar dan motivasi belajar untuk menghasilkan belajar yang baik.

Dalam pembelajaran di kelas, motivasi belajar mahasiswa cenderung rendah. Hal ini disebabkan karena dalam pembelajaran, banyak mahasiswa yang aktif dengan gadgetnya. Dalam perilaku sosial, motivasi belajar adalah hal yang sangat penting. Motivasi bagi siswa dapat mengembangkan aktifitas dan inisiatif, dapat mengarahkan akan memelihara ketekunan dalam melakukan kegiatan. Tanpa adanya motivasi terkadang siswa sangat malas dalam melakukan aktivitas. Motivasi belajar sangat berperan mendorong peserta didik mencapai keberhasilan dalam berperilaku sosial.

Rendahnya motivasi belajar juga dialami oleh mahasiswa Universitas Pamulang. Salah satu yang menyebabkan rendahnya motivasi siswa tersebut adalah makin seringnya mahasiswa aktif dengan media sosialnya. Perkembangan sosial pada remaja menjadi aspek penting yang harus diperhatikan. Tidak sedikit permasalahan yang timbul pada remaja dilatarbelakangi oleh perkembangan sosial yang tidak stabil. Keberhasilan perkembangan sosial bersinggungan dengan proses membangun hubungan dengan lingkungan sekitar. Salah satu kunci keberhasilan membangun hubungan yang baik adalah dengan adanya proses berkomunikasi.

Teknologi komunikasi yang saat ini digunakan oleh berbagai kalangan adalah media sosial. Menurut Andarwati dan Sankarto dalam Shella Anggraini (2019) Intensitas akses internet adalah gambaran berapa lama dan sering seseorang menggunakan internet dengan berbagai tujuan atau motivasi. Misalnya BBM, Line, twitter, instagram, whatsapp, facebook, skype dan sebagainya.

Data statistik mengenai media sosial dan aplikasi chatting yang paling sering digunakan oleh masyarakat Indonesia, menurut JAKPAT mobile survey Januari 2020, Facebook menempati peringkat pertama penggunaan media sosial di Indonesia dengan presentase $86,2 \%$, peringkat kedua Youtube dengan presentase $82,8 \%$, ketiga adalah Instagram dengan presentase $75,0 \%$, keempat Twitter dengan presentase 37,5\%, kelima Pinterest dengan presentase $13,8 \%$, keenam Snapchat dengan presentase $11,1 \%$, ketujuh Linkedin dengan presentase 10,0\%.

Disamping itu WeAreSocial bekerjasama dengan Hootsuite melaporkan bahwa pada tahun 2018 Indonesia menempati peringkat keempat dunia dengan durasi rata-rata penggunaan internet selama 8 jam 51 menit setiap harinya, penggunaan internet tersebut didominiasi oleh aktifitas bersosialisasi di dunia maya. $49 \%$ populasi pengguna internet di Indonesia telah memiliki sosial media. Dalam hal pertumbuhan pengguna sosial media, Indonesia merupakan negara ketiga terbesar dengan tingkat pertumbuhan mencapai $23 \%$ atau 24 juta pengguna dalam satu tahun terakhir. 
Dalam segi lama durasi menggunakan sosial media, Indonesia menempati peringkat tertinggi dengan durasi 3 jam 23 menit dalam satu hari, durasi ini bila dibandingkan dengan jumlah ratarata penggunaan internet orang Indonesia, maka orang Indonesia mengalokasikan hampir 30\% waktunya untuk menggunakan media sosial. Instagram merupakan salah satu media sosial terpopuler di Indonesia dengan jumlah pengguna mencapai 53 juta orang dengan kata lain hampir seluruh pengguna smartphone di Indonesia merupakan pengguna instagram.

Dengan menurunnya motivasi belajar dan meningkatnya intensi pengguna media sosial maka berubah pula kepedulian sosial yang terjadi pada mahasiswa Universitas pamulang berdasarkan latar belakang peneliti tertarik untuk membahas topik terkait perubahan kepedulian sosial mahasiswa akibat menurunnya motivasi belajar beserta meningkatnya intensi pengguna media sosial tersebut.

\section{METODE}

Pengertian metode penelitian menurut Sugiyono (2014) adalah cara ilmiah untuk mendapatkan data yang valid dengan tujuan dapat ditemukan, dibuktikan, dikembangkan suatu pengetahuan tertentu sehingga pada gilirannya dapat digunakan untuk memahami, memecahkan dan mengantisipasi masalah. Objek penelitian adalah Yayasan Sasmita Jaya, Universitas Pamulang yang beralamat di Jalan Surya Kencana No. 1, Pamulang, Tangerang Selatan. Untuk waktu pelaksanaan penelitian akan dimulai pada bulan Januari 2020 sampai dengan Oktober 2020.

Data yang akan digunakan dalam penelitian ini adalah data kuesioner karyawan yang memenuhi kriteria tertentu. Data yang diperoleh akan diolah sesuai dengan kepentingan penelitian dan selanjutnya akan disajikan dalam bentuk tabel. Kemudian peneliti membuat rancangan analisis data dengan menggunakan program Ms. Excel dan analisis statistik menggunakan program SPSS 21.

Sebelum pengolahan data, penulis menentukan populasi dan sampel sebagai berikut:

\section{Penentuan Populasi}

Dalam suatu penelitian populasi merupakan sekumpulan objek yang ditentukan melalui suatu kriteria tertentu yang akan dikategorikan ke dalam objek tersebut, bisa termasuk orang, dokumen atau catatan yang dipandang sebagai objek penelitian. Menurut Sugiyono (2016) mendefinisikan populasi sebagai berikut : "Populasi adalah wilayah generalisasi yang terdiri atas ; obyek/subyek yang mempuyai kualitas atau karakteristik tertentu yang ditetapkan oleh peneliti untuk dipelajari dan kemudian ditarik kesimpulannnya".

Dari definisi diatas, maka yang dimaksud dengan populasi bukan sekedar jumlah yang ada pada objek atau subjek yang dipelajari, tetapi meliputi seluruh karakteristik atau sifat yang dimiliki oleh subjek atau objek tersebut. Dalam penelitian ini yang dijadikan populasi adalah mahasiswa Universitas Pamulang Tingkat 2 Fakultas Ekonomi Jurusan Manajemen Kelas Eksekutif sebanyak 1449 orang.

\section{Penentuan Sampel}

Menurut Sugiyono (2016) yang dimaksud "Sampel adalah bagian dari jumlah dan karakteristik yang dimiliki oleh sampel tersebut".

Teknik Sampling

Menurut Sugiyono (2016), yang dimaksud "Teknik sampling adalah merupakan teknik pengambilan sampel, untuk menentukan sampel yang akan digunakan dalam penelitian", dalam penelitian ini penulis menggunakan metode simpel random sampling, dimana setiap elemen atau anggota populasi memiliki kesempatan yang sama untuk terpilih menjadi sampel.

\section{HASIL}

\section{Uji Regresi Linear}

Analisis regresi linier digunakan oleh peneliti bila peneliti bermaksud meramalkan bagaimana keadaan (naik turunnya) variabel dependen (kriterium), bila ada satu variabel independen sebagai predictor dimanipulasi (dinaik turunkan nilainya). Dalam penelitian ini analis regresi dilakukan secara sederhana dan berganda. Berikut hasil uji regresi linear sederhana dan berganda sebagai berikut:

Analisa Regresi Linear Sederhana Motivasi (X1) Terhadap Kepedulian Sosial (Y)

Hasil output regresi linear sederhana $\mathrm{Y}=\mathrm{a}+$ b(x) antara Motivasi (X1) Terhadap Kepedulian Sosial (Y) sebagaimana pada Tabel 1. 
Tabel 1. Output Regresi Linear Sederhana Motivasi (X1) Terhadap Kepedulian Sosial (Y)

Coefficients $^{\mathrm{a}}$

\begin{tabular}{|c|c|c|c|c|c|c|}
\hline & \multirow{2}{*}{ Model } & \multicolumn{2}{|c|}{ Unstandardized Coefficients } & \multirow{2}{*}{$\begin{array}{c}\text { Standardized } \\
\text { Coefficients } \\
\text { Beta }\end{array}$} & \multirow[t]{2}{*}{$\mathbf{T}$} & \multirow{2}{*}{ Sig. } \\
\hline & & B & Std. Error & & & \\
\hline \multirow{2}{*}{1} & (Constant) & 25.142 & 1.743 & & 14.424 & .000 \\
\hline & Motivasi Total & .424 & .048 & .429 & 8.863 & .000 \\
\hline
\end{tabular}

a. Dependent Variable: Kepedulian Sosial Total

Berdasarkan tabel output di atas dapat dijelaskan bahwa, persamaan regresi linear sederhana $\mathrm{Y}=\mathrm{a}+\mathrm{b}(\mathrm{x})$ adalah $\mathrm{Y}=25,142$ $+0,424(\mathrm{x} 1)$. Persamaan regresi ini dapat disimpulkan bahwa, terdapat pengaruh positif antara Motivasi (X1) Terhadap Kepedulian Sosial (Y).

Konstanta $\mathrm{a}=25,142$ menunjukkan bahwa, nilai Kepedulian Sosial (Y) saat ini diasumsikan bernilai 25,142 satuan dengan asumsi variabel Motivasi (X1) bernilai tetap.

Konstanta $\mathrm{b}=0,424$ menunjukkan bahwa, jika terdapat kenaikan satu-satuan pada variabel Motivasi (X1) maka nilai Kepedulian Sosial (Y) akan bertambah sebesar 0,424 satuan.

Analisa Regresi Linear Sederhana Intensi Pengguna Media Sosial (X2) Terhadap Kepedulian Sosial (Y)

Hasil output regresi linear sederhana $\mathrm{Y}=\mathrm{a}+$ $\mathrm{b}(\mathrm{x})$ antara Intensi Pengguna Media Sosial (X2) Terhadap Kepedulian Sosial (Y) sebagaimana pada Tabel 2.
Berdasarkantabeloutputdiatas dapatdijelaskan bahwa, persamaan regresi linear sederhana $\mathrm{Y}=\mathrm{a}$ $+\mathrm{b}(\mathrm{x})$ adalah $\mathrm{Y}=22,989+0,472(\mathrm{x} 2)$. Persaman regresi ini dapat disimpulkan bahwa, terdapat pengaruh positif antara Intensi Pengguna Media Sosial (X2) Terhadap Kepedulian Sosial (Y).

Konstanta $\mathrm{a}=22,989$ menunjukkan bahwa, nilai Kepedulian Sosial (Y) saat ini diasumsikan bernilai 22,989 satuan dengan asumsi variabel Intensi Pengguna Media Sosial (X2) bernilai tetap.

Konstanta $\mathrm{b}=0,472$ menunjukkan bahwa, jika terdapat kenaikan satu-satuan pada variabel Intensi Pengguna Media Sosial (X2) maka nilai Kepedulian Sosial (Y) akan bertambah sebesar 0,472 satuan.

Analisa Regresi Linear Berganda Motivasi (X1) dan Intensi Pengguna Media Sosial (X2) Terhadap Kepedulian Sosial (Y)

Hasil output regresi linear berganda $\mathrm{Y}=$ $\mathrm{a}+\mathrm{b} 1 \mathrm{x} 1+\mathrm{b} 2 \mathrm{x} 2$ antara Motivasi (X1) dan Intensi Pengguna Media Sosial (X2) Terhadap Kepedulian Sosial (Y) sebagaimana pada Tabel 3.

Tabel 2. Output Regresi Linear Sederhana Intensi Pengguna Media Sosial (X2) Terhadap Kepedulian Sosial (Y) Coefficients $^{\mathrm{a}}$

\begin{tabular}{|c|c|c|c|c|c|c|}
\hline & \multirow{2}{*}{ Model } & \multicolumn{2}{|c|}{ Unstandardized Coefficients } & \multirow{2}{*}{$\begin{array}{c}\text { Standardized } \\
\text { Coefficients } \\
\text { Beta } \\
\end{array}$} & \multirow{2}{*}{$\mathbf{T}$} & \multirow{2}{*}{ Sig. } \\
\hline & & B & Std. Error & & & \\
\hline \multirow{2}{*}{1} & (Constant) & 22.989 & 1.736 & & 13.241 & .000 \\
\hline & Intesi Internet Total & .472 & .046 & .478 & 10.145 & .000 \\
\hline
\end{tabular}

a. Dependent Variable: Kepedulian Sosial Total

Tabel 3. Output Regresi Linear Berganda Motivasi (X1) dan Intensi Pengguna Media Sosial (X2) Terhadap Kepedulian Sosial (Y)

Coefficients $^{\mathrm{a}}$

\begin{tabular}{|c|c|c|c|c|c|c|c|c|}
\hline & \multirow{2}{*}{ Model } & \multicolumn{2}{|c|}{$\begin{array}{c}\text { Unstandardized } \\
\text { Coefficients }\end{array}$} & \multirow{2}{*}{$\begin{array}{c}\text { Standardized } \\
\text { Coefficients } \\
\text { Beta }\end{array}$} & \multirow[t]{2}{*}{$\mathbf{t}$} & \multirow[t]{2}{*}{ Sig. } & \multicolumn{2}{|c|}{ Collinearity Statistics } \\
\hline & & B & Std. Error & & & & Tolerance & VIF \\
\hline & (Constant) & 18.578 & 1.917 & & 9.691 & .000 & & \\
\hline 1 & Motivasi Total & .251 & .052 & .254 & 4.809 & .000 & .750 & 1.334 \\
\hline & Intesi Internet Total & .346 & .052 & .351 & 6.653 & .000 & .750 & 1.334 \\
\hline
\end{tabular}

a. Dependent Variable: Kepedulian Sosial Total 
Berdasarkan tabel output di atas dapat dijelaskan bahwa, persamaan regresi linear berganda $\mathrm{Y}=\mathrm{a}+\mathrm{b} 1 \mathrm{x} 1+\mathrm{b} 2 \mathrm{x} 2$ adalah $\mathrm{Y}=18,578$ $+0,251(\mathrm{x} 1)+0,346(\mathrm{x} 2)$. Persamaan regresi ini dapat disimpulkan bahwa, terdapat pengaruh positif antara Motivasi (X1) dan Intensi Pengguna Media Sosial (X2) Terhadap Kepedulian Sosial (Y).

Konstanta $\mathrm{a}=18,578$ menunjukkan bahwa, nilai Kepedulian Sosial (Y) saat ini diasumsikan bernilai 18,578 satuan dengan asumsi variabel Motivasi (X1), Intensi Pengguna Media Sosial (X2), dan Kepedulian Sosial (Y) bernilai tetap.

Konstanta b1 $1 \times 1=0,251$ menunjukkan bahwa, jika terdapat kenaikan satu-satuan pada variabel Motivasi (X1) maka nilai Kepedulian Sosial (Y) akan bertambah sebesar 0,251 satuan.

Konstanta b2x2 $=0,346$ menunjukkan bahwa, jika terdapat kenaikan satu-satuan pada variabel Intensi Pengguna Media Sosial (X2) maka nilai Kepedulian Sosial (Y) akan bertambah sebesar 0,346 satuan.

\section{Uji Hipotesis}

Hipotesis adalah dugaan terhadap hubungan antara dua variabel atau lebih.Atas dasar definisi tersebut dapat diartikan bahwa hipotesis adalah jawaban atau dugaan sementara yang harus di uji kebenarannya. Hipotesis penelitian di uji dengan menggunakan uji parsial dan uji simultan.

\section{Uji Parsial (Uji t)}

Uji $t$ digunakan untuk mengetahui apakah variabel bebas signifikan atau tidak terhadap variabel terikat secara individual untuk setiap variable. Selanjutnya digunakan tabel distribusi "t" pada derajat kebebasan $(\mathrm{dk})=\mathrm{n}-2$ untuk mengetahui ditolak atau tidaknya suatu hipotesis.
Dengan tingkat signifikansi $(\alpha)=0,05$ dan derajat kebebasan $(\mathrm{dk})=\mathrm{n}-2$ maka kriteria uji t:

Selanjutnya untuk mengetahui signifikansi bandingkan antara nilai probabilitas 0,05 dengan nilai probabilitas Sig sebagai berikut:

Jika thitung $\leq$ ttabel 1,967 atau nilai probabilitas 0,05 lebih kecil atau sama dengan nilai probabilitas Sig atau $(0,05 \geq \mathrm{Sig})$, maka Ho diterima dan Ha ditolak artinya tidak signifikan.

Jika thitung $>$ ttabel 1,967 atau nilai probabilitas 0,05 lebih besar atau sama dengan nilai probabilitas Sig atau $(0,05<\mathrm{Sig})$, maka Ho ditolak dan Ha diterima artinya signifikan.

$\mathrm{T}$ tabel $=1,967$ di dapat dengan ketentuan :

$\mathrm{n} \quad=350$ jumlah sampel

$\alpha \quad=5 \%$ tingkat signifikan

$\mathrm{dk} \quad=\mathrm{n}-2 \quad$ derajat kebebasan

$\mathrm{t}$ tabel $=\alpha, \mathrm{n}-2 \quad(350-2=348)$

$\mathrm{t}$ tabel $=5 \%, 348$

$\mathrm{t}$ tabel $=1,967$ (tabel distribusi $\mathrm{t}$ )

Uji Hipotesis Parsial Motivasi (X1) Terhadap Kepedulian Sosial (Y)

Hipotesis yang diajukan dalam pengujian Motivasi (X1) Terhadap Kepedulian Sosial (Y) yaitu:

Ho1 : Tidak terdapatpengaruh positifdan signifikan Motivasi (X1) Terhadap Kepedulian Sosial (Y) pada Mahasiswa Universitas Pamulang Tingkat 2 Fakultas Ekonomi Jurusan Manajemen Kelas Eksekutif.

Ha1 : Terdapat pengaruh positif dan signifikan Motivasi (X1) Terhadap Kepedulian Sosial (Y) pada Mahasiswa Universitas Pamulang Tingkat 2 Fakultas Ekonomi Jurusan Manajemen Kelas Eksekutif.

Hasil pengujian hipotesis secara parsial adalah sebagaimana pada Tabel 4.

Tabel 4. Output Uji Hipotesis Motivasi (X1) Terhadap Kepedulian Sosial (Y)

Coefficients $^{\mathrm{a}}$

\begin{tabular}{|c|c|c|c|c|c|c|}
\hline \multirow{2}{*}{\multicolumn{2}{|c|}{ Model }} & \multicolumn{2}{|c|}{ Unstandardized Coefficients } & \multirow{2}{*}{$\begin{array}{c}\text { Standardized } \\
\text { Coefficients } \\
\text { Beta }\end{array}$} & \multirow[t]{2}{*}{$\mathbf{T}$} & \multirow{2}{*}{ Sig. } \\
\hline & & B & Std. Error & & & \\
\hline & (Constant) & 25.142 & 1.743 & & 14.424 & .000 \\
\hline & Motivasi Total & .424 & .048 & .429 & 8.863 & .000 \\
\hline
\end{tabular}

a. Dependent Variable: Kepedulian Sosial Total

Berdasarkan tabel output coefficients di atas dapat disimpulkan bahwa nilai $\mathrm{t}$ hitung variabel Motivasi (X1) terhadap Kepedulian Sosial (Y) sebesar $\mathrm{t}$ hitung $8,863>\mathrm{t}$ tabel 1,967 atau nilai Sig $0,000<0,05$ maka Ho1 di tolak dan artinya 
terdapat pengaruh positif dan signifikan antara Motivasi (X1) terhadap Kepedulian Sosial (Y).

Uji Hipotesis Parsial Intensi Pengguna Media Sosial (X2) Terhadap Kepedulian Sosial (Y)

Hipotesis yang diajukan dalam pengujian Intensi Pengguna Media Sosial (X2) Terhadap Kepedulian Sosial (Y) adalah:

Ho2 : Tidak terdapat pengaruh positif dan signifikan Intensi Pengguna Media Sosial (X2) Terhadap Kepedulian Sosial (Y) pada Mahasiswa Universitas Pamulang Tingkat 2 Fakultas Ekonomi Jurusan Manajemen Kelas Eksekutif.

Ha2 : Terdapat pengaruh positif dan signifikan Intensi Pengguna Media Sosial (X2) Terhadap Kepedulian Sosial (Y) pada Mahasiswa Universitas Pamulang Tingkat 2 Fakultas Ekonomi Jurusan Manajemen Kelas Eksekutif.

Hasil Output uji hipotesis secara parsial sebagaimana pada Tabel 5. $\alpha=5 \%$ tingkat signifikansi / tingkat kesalahan

$\mathrm{n} \quad=350$ jumlah sampel

$\mathrm{m}=3 \quad$ jumlahvariabel

$\mathrm{v} 1=\mathrm{m}-1$

$\mathrm{v} 1=3-1=2$

$\mathrm{v} 2=\mathrm{n}-\mathrm{m}$

v2 $=350-3=347$

$\mathrm{F}$ tabel $=5 \%, \mathrm{v} 1, \mathrm{v} 2$

$\mathrm{F}$ tabel $=5 \%, 2,347$

$\mathrm{F}$ tabel $=3,04$

Ho diterima dan Ha ditolak jika $\mathrm{F}$ hitung $\leq \mathrm{F}$ table 3,04 atau probabilitas Sig $0,000 \geq 0,05$

Ho ditolak dan Ha diterima jika $\mathrm{F}$ hitung $>\mathrm{F}$ tabel. 3,04 atau probabilitas Sig 0,000 $<0,05$

Hipotesis yang diajukan dalam pengujian pengaruh secara simultan adalah:

Ho3 : Tidak terdapatpengaruh positifdan signifikan

Tabel 5. Output Uji Hipotesis Intensi Pengguna Media Sosial (X2) Terhadap Kepedulian Sosial (Y)

Coefficients $^{\mathrm{a}}$

\begin{tabular}{|c|c|c|c|c|c|c|}
\hline \multirow{2}{*}{\multicolumn{2}{|c|}{ Model }} & \multicolumn{2}{|c|}{ Unstandardized Coefficients } & \multirow{2}{*}{$\begin{array}{l}\text { Standardized } \\
\text { Coefficients } \\
\text { Beta }\end{array}$} & \multirow{2}{*}{$\mathbf{T}$} & \multirow{2}{*}{ Sig. } \\
\hline & & B & Std. Error & & & \\
\hline \multirow{2}{*}{1} & (Constant) & 22.989 & 1.736 & & 13.241 & .000 \\
\hline & Intesi Internet Total & .472 & .046 & .478 & 10.145 & .000 \\
\hline
\end{tabular}

a. Dependent Variable: Kepedulian Sosial Total

Nilai t hitung variabel Intensi Pengguna Media Sosial (X2) terhadap Kepedulian Sosial (Y) sebesar t hitung 10,145 > t tabel 1,967 atau nilai Sig 0,000< 0,05 maka Ho2 di tolak dan artinya terdapat pengaruh positif dan signifikan antara Intensi Pengguna Media Sosial (X2) terhadap Kepedulian Sosial (Y).

\section{Uji Hipotesis Simultan (Uji F)}

Uji F digunakan untuk mengetahui pengaruh variabel bebas secara bersama-sama (simultan) terhadap variabel terikat.

Dengan taraf nyata yang biasa digunakan 5\% $(0,05)$, sedangkan nilai $\mathrm{F}$ tabel dengan derajat bebas (db), $V_{1}=m-1 ; V_{2}=n-m$
Motivasi (X1) dan Intesi Pengguna Media Sosial (X2) Terhadap Kepedulian Sosial (Y) pada Mahasiswa Universitas Pamulang Tingkat 2 Fakultas Ekonomi Jurusan Manajemen Kelas Eksekutif.

Ha3 : Terdapat pengaruh positif dan signifikan Motivasi (X1) dan Intesi Pengguna Media Sosial (X2) Terhadap Kepedulian Sosial (Y) pada Mahasiswa Universitas Pamulang Tingkat 2 Fakultas Ekonomi Jurusan Manajemen Kelas Eksekutif.

Hasil output uji hipotesis simultan Motivasi (X1) dan Intesi Pengguna Media Sosial (X2) Terhadap Kepedulian Sosial (Y) sebagaimana pada Tabel 6.

Tabel 6. Uji Hipotesis Simultan Motivasi (X1) dan Intensi Pengguna Media Sosial (X2) Terhadap Kepedulian Sosial (Y) ANOVA $^{\mathrm{a}}$

\begin{tabular}{llcccc}
\hline \multicolumn{1}{c}{ Model } & $\begin{array}{c}\text { Sum of } \\
\text { Squares }\end{array}$ & Df & Mean Square & F & Sig. \\
\hline Regression & 2244.523 & 2 & 1122.262 & 66.295 & $.000^{\text {b }}$ \\
1 Residual & 5874.151 & 347 & 16.928 & & \\
Total & 8118.674 & 349 & & & \\
\hline
\end{tabular}

a. Dependent Variable: Kepedulian Sosial Total

b. Predictors: (Constant), Intesi Internet Total, Motivasi Total 
Melihat tabel output di atas dapat dijelaskan bahwa, Fhitung 66,295 $>$ F tabel 3,04 atau probabilitas Sig $0,000<0,05$ maka $\mathrm{Ho} 3$ di tolak dan $\mathrm{Ha} 3$ di terima artinya signifikan dengan demikian hipotesis yang diajukan menetapkan terdapat pengaruh positif dan signifikan secara bersama-sama antara Motivasi (X1) dan Intensi Pengguna Media Sosial (X2) Terhadap Kepedulian Sosial (Y) pada Mahasiswa Universitas Pamulang Tingkat 2 Fakultas Ekonomi Jurusan Manajemen Kelas Eksekutif.

\section{Koefisien Determinasi}

Koefisien determinasi adalah kadar kontribusi variabel bebas terhadap variabel terikat. Koefisien determinasi dilambangkan R2..

Berikut hasil koefisien determinasi:

\section{Koefisien Determinasi Motivasi (X1) Terhadap Kepedulian Sosial (Y)}

Hasil output koefisien determinasi sebagaimana pada Tabel 7.

\section{Tabel 7. Output Koefisien Determinasi Motivasi}

(X1) Terhadap Kepedulian Sosial (Y)

\section{Model Summary}

\begin{tabular}{ccccc}
\hline Model & $\mathbf{R}$ & $\begin{array}{c}\text { R } \\
\text { Square }\end{array}$ & $\begin{array}{c}\text { Adjusted R } \\
\text { Square }\end{array}$ & $\begin{array}{c}\text { Std. Error of } \\
\text { the Estimate }\end{array}$ \\
\hline 1 & $.429^{\mathrm{a}}$ & .184 & .182 & 4.363 \\
\hline
\end{tabular}

a. Predictors: (Constant), Motivasi Total

Dari tabel di atas dapat dijelaskan bahwa nilai korelasi $\mathrm{R}=0,429$ berada pada rentang $0,400-$ 0,599 dengan tingkat hubungan sedang, artinya Motivasi (X1) memiliki tingkat hubungan sedang terhadap Kepedulian Sosial (Y).

Nilai R Square $=0,184$ dapat disimpulkan bahwa, Motivasi (X1) memberikan kontribusi Terhadap Kepedulian Sosial (Y) sebesar 18,4\% dan sisanya $81,6 \%$ dipengaruhi oleh faktor lain.

Koefisien Determinasi Intensi Pengguna Media Sosial (X2) Terhadap Kepedulian Sosial (Y)

Hasil output koefisien determinasi sebagaimana pada Tabel 8 .

Tabel 8. Output Koefisien Determinasi Intensi Pengguna Media Sosial (X2) Terhadap Kepedulian Sosial (Y)

Model Summary

\begin{tabular}{ccccc}
\hline Model & $\mathbf{R}$ & $\begin{array}{c}\text { R } \\
\text { Square }\end{array}$ & $\begin{array}{c}\text { Adjusted R } \\
\text { Square }\end{array}$ & $\begin{array}{c}\text { Std. Error of } \\
\text { the Estimate }\end{array}$ \\
\hline 1 & $.478^{\mathrm{a}}$ & .228 & .226 & 4.243 \\
\hline
\end{tabular}

a. Predictors: (Constant), Intesi Internet Total
Dari tabel di atas dapat dijelaskan bahwa nilai korelasi $\mathrm{R}=0,478$ berada pada rentang $0,400-0,599$ dengan tingkat hubungan sedang, artinya Intensi Pengguna Media Sosial (X2) memiliki tingkat hubungan sedang terhadap Kepedulian Sosial (Y).

Nilai R Square $=0,228$ dapat disimpulkan bahwa, Intensi Pengguna Media Sosial (X2) memberikan kontribusi Terhadap Kepedulian Sosial (Y) sebesar 22,8\% dan sisanya 77,2\% dipengaruhi oleh faktor lain.

Koefisien Determinasi Motivasi (X1) dan Intensi Pengguna Media Sosial (X2) Terhadap Kepedulian Sosial (Y)

Hasil output koefisien determinasi sebagaimana pada Tabel 9.

Tabel 9. Output Koefisien Determinasi Motivasi

(X1) dan Intensi Pengguna Media Sosial (X2) Terhadap Kepedulian Sosial (Y)

Model Summary

\begin{tabular}{cccccc}
\hline Model & $\mathbf{R}$ & $\begin{array}{c}\mathbf{R} \\
\text { Square }\end{array}$ & $\begin{array}{c}\text { Adjusted R R } \\
\text { Square }\end{array}$ & $\begin{array}{c}\text { Std. } \\
\text { Error } \\
\text { of the } \\
\text { Estimate }\end{array}$ & $\begin{array}{c}\text { Durbin- } \\
\text { Watson }\end{array}$ \\
\hline 1 & $.526^{\mathrm{a}}$ & .276 & .272 & 4.114 & 1.985 \\
\hline
\end{tabular}

a. Predictors: (Constant), Intesi Internet Total, Motivasi Total b. Dependent Variable: Kepedulian Sosial Total

Dari tabel di atas dapat dijelaskan bahwa nilai korelasi $\mathrm{R}=0,526$ berada pada rentang 0,400 0,599 dengan tingkat hubungan sedang, artinya Motivasi (X1) dan Intensi Pengguna Media Sosial (X2) memiliki tingkat hubungan kuat terhadap Kepedulian Sosial (Y).

Nilai R Square $=0,276$ dapat disimpulkan bahwa, Motivasi (X1) dan Intensi Pengguna Media Sosial (X2) memberikan kontribusi Terhadap Terhadap Kepedulian Sosial (Y) sebesar 27,6\% dan sisanya $72,4 \%$ dipengaruhi oleh faktor lain.

\section{PEMBAHASAN}

\section{Pengaruh Motivasi (X1) Terhadap Kepedulian Sosial (Y)}

Berdasarkan hasil penelitian menunjukkan bahwa, terdapat pengaruh positif dan signifikan antara Motivasi (X1) Terhadap Kepedulian Sosial (Y) pada Mahasiswa Universitas Pamulang Tingkat 2 Fakultas Ekonomi Jurusan Manajemen Kelas Eksekutif. Hal ini dibuktikan dengan persamaan regresi linear sederhana $\mathrm{Y}=\mathrm{a}+$ $\mathrm{b}(\mathrm{x})$ adalah $\mathrm{Y}=25,142+0,424(\mathrm{x} 1)$. Persamaan regresi ini dapat disimpulkan bahwa, terdapat 
pengaruh positif antara Motivasi (X1) Terhadap Kepedulian Sosial (Y). Konstanta a $=25,142$ menunjukkan bahwa, nilai Kepedulian Sosial (Y) saat ini diasumsikan bernilai 25,142 satuan dengan asumsi variabel Motivasi (X1) bernilai tetap. Konstanta $\mathrm{b}=0,424$ menunjukkan bahwa, jika terdapat kenaikan satu-satuan pada variabel Motivasi (X1) maka nilai Kepedulian Sosial (Y) akan bertambah sebesar 0,424 satuan.

Uji hipotesis menunjukkan nilai thitung 8,863 $>$ ttabel 1,967 atau probabilitas Sig 0,000 < 0,05 maka Hol di tolak dan Hal di terima artinya signifikan dengan demikian hipotesis yang diajukan menetapkan Terdapat pengaruh positif dan signifikan Motivasi (X1) terhadap Kepedulian Sosial (Y) Mahasiswa Universitas Pamulang Tingkat 2 Fakultas Ekonomi Jurusan Manajemen Kelas Eksekutif. Nilai korelasi $\mathrm{R}=0,429$ berada pada rentang $0,400-0,599$ dengan tingkat hubungan sedang, artinya Motivasi (X1) memiliki tingkat hubungan sedang terhadap Kepedulian Sosial (Y). Nilai R Square $=0,184$ dapat disimpulkan bahwa, Motivasi (X1) memberikan kontribusi Terhadap Kepedulian Sosial (Y) sebesar 18,4\% dan sisanya $81,6 \%$ dipengaruhi oleh faktor lain.

Hasil penelitian ini sejalan dengan hasil penelitian terdahulu yang telah dilakukan dan diteliti oleh Ibnu Hurri (2015) dengan judul Kontribusi Pembelajaran Ilmu Pengetahuan Sosial Terhadap Kepedulian Sosial Di Kalangan Siswa SMA. Berdasarkan hasil analsis dan pembahasan di bagian sebelumnya dapat disimpulkan bahwa: 1). Hasil penelitian yang telah dilakukan mengenai pembelajaran IPS terhadap kepedulian sosial siswa SMA ada kontribusi yang signifikan, hal ini tercermin pada nilai yang dihasilkan dari perhitungan sebesar $52.7 \%$ sedangkan sisanya $47.3 \%$ dipengaruhi oleh faktor lainnya yang tidak diteliti dalam penelitian ini.

Kemudian, 2). Hasil penelitian menyatakan bahwa pembelajaran IPS terhadap toleransi siswa SMA memberikan kontribusi sebesar $31.7 \%$ atau dikatakan pengaruhnya sedang. 3). Hal ini menunjukkan bahwa pembelajaran IPS terhadap kepedulian sosial khususnya cinta damai memberikan kontribusi sebesar 33.5\%, sedangkan sisanya $66.5 \%$ dipengaruhi oleh faktor lainnya yang tidak diteliti dalam penelitian ini. 4). Hal ini menunjukkan bahwa peduli lingkungan pada siswa tersebut dipengaruhi oleh pembelajaran IPS di kelas, sedangkan sisanya $70.6 \%$ dipengaruhi oeh faktor lainnya yang tidak diteliti dalam penelitian ini.
Selanjutnya, 5). Hasil penelitian yang telah dilakukan mengenai pembelajaran IPS terhadap kepedulian sosial khususnya empati dikalangan siswaSMANegeridiKotaSukabumimenunjukkan $46.2 \%$ dipengaruhi oleh pembelajaran IPS di kelas. 6). Berdasarkan hasil penelitian yang telah dilakukan mengenai pembelajaran IPS terhadap tanggung jawab siswa SMA tingkat keeratan hubungan antara variable pembelajaran IPS terhadap tanggung jawab menunjukkan $65.1 \%$ atau dikatakan pengaruhnya sangat kuat, sedangkan sisanya $34.9 \%$ dipengaruhi oleh faktor lainnya yang tidak diteliti dalam penelitian ini.

\section{Pengaruh Intensi Pengguna Media Sosial (X2) Terhadap Kepedulian Sosial (Y)}

Berdasarkan hasil penelitian menunjukkan bahwa, terdapat pengaruh positif dan signifikan secara secara parsial antara Intensi Pengguna Media Sosial (X2) terhadap Kepedulian Sosial (Y) pada Mahasiswa Universitas Pamulang Tingkat 2 Fakultas Ekonomi Jurusan Manajemen Kelas Eksekutif. Hal ini dibuktikan dengan persamaan regresi linear sederhana $\mathrm{Y}=\mathrm{a}+$ $\mathrm{b}(\mathrm{x})$ adalah $\mathrm{Y}=22,989+0,472(\mathrm{x} 2)$. Persamaan regresi ini dapat disimpulkan bahwa, terdapat pengaruh positif antara Intensi Pengguna Media Sosial (X2) Terhadap Kepedulian Sosial (Y). Konstanta $\mathrm{a}=22,989$ menunjukkan bahwa, nilai Kepedulian Sosial (Y) saat ini diasumsikan bernilai 22,989 satuan dengan asumsi variabel Intensi Pengguna Media Sosial (X2) bernilai tetap. Konstanta $\mathrm{b}=0,472$ menunjukkan bahwa, jika terdapat kenaikan satu-satuan pada variabel Intensi Pengguna Media Sosial (X2) maka nilai Kepedulian Sosial (Y) akan bertambah sebesar 0,472 satuan.

Uji hipotesis menunjukkan nilai thitung $10,145>$ ttabel 1,967 atau probabilitas Sig 0,000 $<0,05$ maka Ho2 di tolak dan Ha2 di terima artinya signifikan dengan demikian hipotesis yang diajukan menetapkan Terdapat pengaruh positif dan signifikan Intensi Pengguna Media Sosial (X2) terhadap Kepedulian Sosial (Y) pada Mahasiswa Universitas Pamulang Tingkat 2 Fakultas Ekonomi Jurusan Manajemen Kelas Eksekutif. Nilai korelasi $\mathrm{R}=0,478$ berada pada rentang 0,400-0,599 dengan tingkat hubungan sedang, artinya Intensi Pengguna Media Sosial (X2) memiliki tingkat hubungan sedang terhadap Kepedulian Sosial (Y). Nilai R Square $=0,228$ dapat disimpulkan bahwa, Intensi Pengguna Media Sosial (X2) memberikan kontribusi 
Terhadap Kepedulian Sosial (Y) sebesar 22,8\% dan sisanya $77,2 \%$ dipengaruhi oleh faktor lain.

Hasil penelitian ini sejalan dengan hasil penelitian terdahulu yang telah dilakukan dan diteliti oleh Eni Marlina dan Lydia Ersta Kusumaningtyas (2018) dengan judul Pengaruh Bimbingan Klasikal Menggunakan Media Film Terhadap Kepedulian Sosial Siswa Kelas VIII SMPN 7 Surakarta Tahun Pelajaran 2017/2018. Berdasarkan hasil penelitian dan pembahasan maka dapat disimpulkan sebagai berikut Ada pengaruh bimbingan klasikal menggunakan media film terhadap kepedullian sosial siswa kelas VIII SMP N 7 Surakarta tahun pelajaran 2017/2018.

\section{Pengaruh Motivasi (X1) dan Intensi Pengguna Media Sosial (X2) Terhadap Kepedulian Sosial (Y)}

Berdasarkan hasil penelitian menunjukkan bahwa, terdapat pengaruh positif dan signifikan secara secara simultan antara Motivasi (X1) dan Intensi Pengguna Media Sosial (X2) terhadap Kepedulian Sosial (Y) pada Mahasiswa Universitas Pamulang Tingkat 2 Fakultas Ekonomi Jurusan Manajemen Kelas Eksekutif. Hal ini dibuktikan dengan berdasarkan tabel Output di atas dapat dijelaskan bahwa, persamaan regresi linear berganda $\mathrm{Y}=\mathrm{a}+\mathrm{b} 1 \mathrm{x} 1+\mathrm{b} 2 \mathrm{x} 2$ adalah $\mathrm{Y}=18,578+0,251(\mathrm{x} 1)+0,346(\mathrm{x} 2)$.

Persaman regresi ini dapat disimpulkan bahwa, terdapat pengaruh positif antara Motivasi (X1) dan Intensi Pengguna Media Sosial (X2) Terhadap Kepedulian Sosial (Y). Konstanta $\mathrm{a}=18,578$ menunjukkan bahwa, nilai Kepedulian Sosial (Y) saat ini diasumsikan bernilai 18,578 satuan dengan asumsi variabel Motivasi (X1) dan Intensi Pengguna Media Sosial (X2) bernilai tetap. Konstanta b1x1 = 0,251 menunjukkan bahwa, jika terdapat kenaikan satu-satuan pada variabel Motivasi (X1) maka nilai Kepedulian Sosial (Y) akan bertambah sebesar 0,251 satuan. Konstanta b2x2 $=0,346$ menunjukkan bahwa, jika terdapat kenaikan satu-satuan pada variabel Intensi Pengguna Media Sosial (X2) maka nilai Kepedulian Sosial (Y) akan bertambah sebesar 0,346 satuan

Uji hipotesis menunjukkan nilai $\mathrm{F}$ hitung $66,295>$ F tabel 3,04 atau probabilitas Sig $0,000<0,05$ maka Ho3 di tolak dan Ha3 di terima artinya signifikan dengan demikian hipotesis yang diajukan menetapkan Terdapat pengaruh positif dan signifikan secara bersama-sama antara Motivasi (X1) dan Intensi Pengguna Media Sosial (X2) terhadap
Kepedulian Sosial (Y) pada Mahasiswa Universitas Pamulang Tingkat 2 Fakultas Ekonomi Jurusan Manajemen Kelas Eksekutif. Nilai korelasi $\mathrm{R}=0,526$ berada pada rentang 0,400-0,599 dengan tingkat hubungan sedang, artinya Motivasi (X1) dan Intensi Pengguna Media Sosial (X2) memiliki tingkat hubungan sedang terhadap Kepedulian Sosial (Y). Nilai $\mathrm{R}$ Square $=0,276$ dapat disimpulkan bahwa, Motivasi (X1) dan Intensi Pengguna Media Sosial (X2) memberikan kontribusi Terhadap Kepedulian Sosial (Y) sebesar 27,6\% dan sisanya $72,4 \%$ dipengaruhi oleh faktor lain.

Hasil penelitian ini sejalan dengan hasil penelitian terdahulu yang telah dilakukan dan diteliti oleh La Moriansyah (2016) dengan judul Motivasi, Sikap, Dan Intensi Pengguna Media Sosial Pada Kampanye Stop Illegal Fishing. Dari hasil penelitian ini dapat disimpulkan bahwa motivasi pengguna untuk menggunakan media sosial dan terhadap pesan kampanye terbukti secara signifikan berpengaruh positif pada sikap pengguna terhadap kampanye sosial di media sosial.

\section{SIMPULAN}

Berdasarkan hasil penelitian secara keseluruhan dapat ditarikkesimpulan hasil uji-t independent sample $t$ test motivasi menunjukkan bahwa nilai Sig. $0,000<0,05$ maka Ha diterima yaitu motivasi berpengaruh signifikan terhadap kepedulian sosial. Berdasarkan hasil penelitian secara keseluruhan dapat ditarikkesimpulan hasil uji-t independent sample $t$ test intensi media sosial menunjukkan bahwa nilai Sig. $0,000<$ 0,05 maka Ha diterima yaitu intensi penggunaan media sosial berpengaruh signifikan terhadap kepedulian sosial. Berdasarkan hasil penelitian secara keseluruhan dapat ditarik kesimpulan hasil uji-f independent sample $\mathrm{f}$ test motivasi dan intensi media sosial menunjukkan bahwa nilai Sig. $0,000<0,05$ maka Ha diterima yaitu motivasi dan intensi penggunaan media sosial berpengaruh signifikan terhadap kepedulian sosial.

\section{PENGHARGAAN}

Terima kasih kepada Direktorat Riset dan Pengabdian Masyarakat Direktorat Jenderal Penguatan Riset dan Pengembangan Kementerian Riset dan Teknologi/Badan Riset dan Inovasi Nasional karena telah membiaya penuh penelitian ini. Selain itu juga saya ucapkan terima kasih kepada Universitas Pamulang karena telah membatu dalam proses penelitian ini. 


\section{DAFTAR PUSTAKA}

Anggraini, S. (2019). Hubungan Regulasi Diri Dengan Intensitas Penggunaan Media Sosial Peserta Didik Kelas X di Ma Al-Hikmahbandar Lampung Tahun Ajaran 2018/2019. Lampung: Universitas Islam Negeri Raden Intan Lampung.

Cruz, M. U. (2017). Konsumen Ramah Lingkungan: Perilaku Konsumsi Hijau Civitas Academica Universitas Diponegoro. Semarang: Universitas Diponegoro.

Damayanti, S. (2019). Hubungan Kebiasaan Belajar Dan Motivasi Belajar Dengan Hasil Belajar PPKn Siswa Kelas IV SD Negeri Gugus Supriyadi Kabupaten Kendal. Semarang: Universitas Negeri Semarang.

Hariyanto, M. S. (2011). Konsep dan Model Pendidikan Karakter. Bandung: Remaja Rosdakarya.

Hurri, I. (2015). Kontribusi Pembelajaran Ilmu Pengetahuan Sosial Terhadap Kepedulian Sosial di Kalangan Siswa SMA. Jakarta: Universitas Pendidikan Indonesia.

Jakpat. (2020, Mei 13). Indonesia Social Media Trend 2020-Survey Report. Retrieved Juni 1, 2020, from blog.jakpat.net: https://blog.jakpat. net/indonesia-social-media-trend-1 st-semesterof-2020-jakpat-survey-report-free-version/.

Kusumaningtyas, E. M. (2018). Pengaruh Bimbingan Klasikal Menggunakan Media Film Terhadap Kepedulian Sosial Siswa Kelas VIII
SMPN 7 Surakarta Tahun Pelajaran 2017/2018. MEDIKons, 4 (2), 34-41.

Moriansyah, L. (2016). Motivasi, Sikap, Dan Intensi Pengguna Media Sosial Pada Kampanye Stop Illegal Fishing. Jurnal Manajemen \& Agribisnis, 13 (3), 192-205.

Rahmawati, H. N., Iqomh, M. K. B., \& Hermanto (2017). Hubungan Durasi Penggunaan Media Sosial Dengan Motivasi Belajar Remaja. Jurnal Keperawatan Jiwa, 5 (2), 77-81.

Riyanto, A. D. (2019, April 5). Hootsuite (We are Social): Indonesian Digital Report 2019. Retrieved Juni 5,2020, fromandi.link: https://andi.link/hootsuitewe-are-social-indonesian-digital-report-2019/.

Simaguna, H. L., Kristayulita \& Kurniawati, K. R. A. (2020). Hasil dan Motivasi Belajar Siswa Menggunakan Pembelajaran Kooperatif Tipe STAD. Jurnal Tadris Matematika, 3 (1), 67-76.

Sugiyono. (2014). Metode Penelitian Pendidikan Pendekatan Kuantitatif, Kualitatif, dan R\&D. Bandung: Alfabeta.

Sugiyono.(2016).MetodePenelitian Kuantitatif, Kualitatif dan $R \& D$. Bandung: Alfabeta.

Susilo, B. (2018). Pemasaran Digital: Segmentasi Demografi Pengguna Media Sosial di Kota Pontianak. Jurnal Eksplora Informatika, $8(1), 69-79$.

Uno, H. B. (2011). Teori Motivasi dan Pengukurannya: Analisis di Bidang Pendidikan. Jakarta: Bumi Aksara. 